\title{
Examining Employee's Compensation Satisfaction and Work Stress in A Retail Company and Its Effect to Increase Employee Job Satisfaction
}

\author{
Arif Partono Prasetio, \\ School Economic \& Business, Telkom University, Bandung, Indonesia \\ Bachruddin Saleh Luturlean \\ School Communication \& Business, Telkom University, Bandung, Indonesia
}

Chita Agathanisa

School Economic \& Business, Telkom University, Bandung, Indonesia

Received: April 7, 2019 Accepted: May 7, 2019 Online published: May 16, 2019

doi:10.5296/ijhrs.v9i2.14791 URL: https://doi.org/10.5296/ijhrs.v9i2.14791

\begin{abstract}
Employees are considered as important asset of business organization.Their satisfaction in doing the job is vital to the performance achievement, both for individual and organization. The retail industry also face similar challenge to develop program that enhance job satisfaction for employee. This study examine the relationship among compensation, work stress, and job satisfaction in a retail company in Samarinda. Questionnaires were distributed to 146 employees and a total of 107 usable responses were returned. Data analysis conducted by using regression with bootstrapping and found that compensation did not have effect on work stress. On the other hand, compensation has significant positive relation towards job satisfaction. Work stress also have effect on job satisfaction but in reverse direction (negative). With this kind of relation, work stress obviously did not mediate the relation between compensation and job satisfaction. Retail organization still need to develop interesting compensation packages to keep the satisfaction level of the employee. If they want to help employee to manage the stress level, compensation is not the right solution. The effect of work stress against job satisfaction is relatively small, which mean organization need to combine compensation with other factors if they want to enhance job satisfaction.
\end{abstract}


Keywords: compensation, stress, job satisfaction

\section{Introduction}

The important role of human resources in business organizations has long been known. The human resources department has the responsibility to manage these human assets so they can contribute optimally. All human resources function should carefully implemented and must be interrelated if they want to achieve great result. Most importantly, good human resources management will promote good work environment which in the end can affect employee's job satisfaction. But, employee's satisfaction is not just about providing satisfaction. In fact if an organization wrongly execute job satisfaction program they risk to drive talented employees out. Well planned job satisfaction program should focus on employees who are adding the great value for the organization. Satisfied employees who were happy with their current situation which only doing the job that require little effort can become burden in the future (Rai, 2016). They are happy because they have job with quite good salary with no or just small responsibility. Such employees are not adding value to the organization. It is clear that is not the organization's goal when considering job satisfaction program. They must create suportive and challenging environment at work. Empowerment, recognition, compensation and benefit, attractive job, management support, give more responsibility, provide adequate resources or tools to conduct the job, and respect were some of good choices to begain with. The crucial factor with job satisfaction is that satisfied employees should do the job better and make more contributions.

Job satisfaction is known to have a positive influence on the survival of the organization. Uzer (2017) argue that happy employee will make customers happy. This mean that job satisfaction can have positive impact on business result. Recently, business leaders have begun to focus on how to increase employee happiness. Big companies like Googles and Facebooks provide impressive office perks such as napping pods, cafes, and game rooms. They want their employees to feel enjoy and relax but still provide great contributions. Companies that have tried to increase employee's job satisfaction seem to have realized that from this satisfaction they will get far greater benefits. Robbins and Judge (2017) poses the outcomes of job satisfaction including job performance, organizational citizenship behavior, customer satisfaction and life satisfaction. Otherwise employee's dissatisfaction will result in non-productive work behavior, absenteisme, turnover, and employee voice (complaint). This is reinforced by Griffin \& Moorehead (2014) that a satisfied employee tends to be absent less often, to make positive contributions, and to stay with the organization, while dissatisfied employee may be absent more often, may experience stress that disrupts coworkers, and may be continually looking for another job. Recent studies also confirm these ideas. Prasetio et al. (2017) who studied hotel employees found that job satisfaction significanty has positive effect on affective commitment and organizational citizenship behavior. Job satisfaction also has positive correlation with work motivation (Maharjan, 2012). Job performance and employee loyalty can also increased by developing job satisfaction (Onsardi et al., 2016; Darma \& Supriyanto, 2017).

The accumulating evidences that support the importance of job satisfaction on various 
organizational outcomes stimulate the studies investigating its predictors (Aydogmus et al., 2017). Finding in United States reveal that the biggest predictors of job satisfaction is respect treatment from employeer (SHRM, 2016). Followed by financial features of a job such as salary and benefits, conformity with company culture, feeling appreciated, and level of bonding between employees, management and their organization. Moreover, meta-analysis study from Choi \& Kim (2016), Cass et al. (2003), and Zangaro \& Soeken (2007) provide information that the level of stress will impact the job satisfaction of employees. Other meta-analysis studies found the effect of leadership style on job satisfaction (Karadag, 2015; Sun et al., 2016). Factors that are also considered to have a relationship with job satisfaction are work stress (Trivellasa et al., 2013), perceive organizational support (Alcover et al., 2018), personality (Matzler \& Rentl, 2007), learning organization (Dirani, 2009), compensation (Peprah-mensa et al., 2017), organizational justice (Sieger et al., 2011), learning culture (Pasebani et al., 2012), work-life balance (Azeem \& Akhtar, 2014).

Retail business as in other business organization seek operational effectiveness and efficiency to gain their financial goals. They also faced intense competition. Despites its $10 \%$ growth in 2014, retailers face challenges in form of tighter competition, increasing operational costs, and government regulations (Dewi, 2014). Although faced with all these challenges, retail sector still need to expand. Expansion is a way to strengthen the company because it relates with their market share. They also need to innovate and develop product diversity, maintaining efficiency and implemented new technological in the services. Recently, they also face new competition in the form of e-commerce. Traditional retail need to change their business process to overcome online shops or e-commerce. The rising of internet and smartphone use and supported with improving telecommunication infrastructure, customers have plenty of choices to buy goods and services through online channel. They often get more competitive prices and convenience shopping experience from home. The role of traditional retail companies is surely on the decline if they can not come up with new offers. Although this condition only occurs in large cities and the market share of online retail still only $1.8 \%$, traditional retailer should be prepared (Rahmah \& Hamdi, 2017). In first semester of 2017, retail growth in Indonesia was 3.7\%. Only one third from the same period from previous year (Margrit, 2017). This should awaken the retailers that they must create various efforts to maintain market share. Moreover, the retail condition in 2018 has also not improved. Several offline retail close their shops (Primadhyta, 2018).

Facing with the uncertainty, retailer must rely on their human assets. Human capital can be a crucial items in their arsenal to compete. Competitive advantage can be raised from reliable human resources. In order to drive their human capital to their limit and turn them to high performer, company should come up with innovative strategy to burst employee morale. Faced with a heavy workload and challenging conditions, employee need something of value as a form of exchange. Such stressful situation can be manage in order to avoid becoming distress, which is negative. This study examine the effect of compensation satisfaction on employee's job satisfaction with the mediation of work stress. Financial and other form of compensation can be helpful to keep high level of job satisfaction. However company must pay careful attention what kind of compensation that suit the employee's need. The right 
combination of compensation packages can also help employee to reduce the stress level. Money considered as important recources. Holding large or adequate amounts of money can create a calm effect because the money is resources that is ready for use. They can meet what they want with money from compensation. This condition can lessen stress. Individual with resources can depend on it when they need it. They less likely worry simply because they have quite resources to deal with any demand. With the appropriate compensation packages which meet their need, employees expected to experience less stress and in the end they can enjoy their work and develop high job satisfaction. The contribution of the study is the use of stress as mediation which is still limited in Indonesia. By examining the indirect effect of work stress in the relation of compensation satisfaction and job satisfaction organization could prepare themselves to develop essential programs which is suitable to build talented and loyal employees.

\section{Literature Review and Hypotheses}

\subsection{Compensation}

Compensation includes any forms of payments from organization to employee because of their contribution in doing their jobs (Dessler, 2013). There are two types of compensation; direct financial (including wages, salaries, incentives, commissions, and bonuses) and indirect financial (benefits such as insurance, vacations, child/family support). Martocchio (2015) defined that compensation can be in the form of intrinsic and extrinsic rewards received by employees for performing the jobs. Other definition from Gomez-Mejia et al. (2012) defined compensation as the package of quantifiable rewards from organization to their employee for their labours. Mondy \& Martocchio (2016) gave detail explanation of compensation as the total of all rewards provided for employees in return for their work. The components of this total compensation program include direct and indirect financial compensation and nonfinancial compensation. Payments in terms of wages, salary, commisions, \& bonuses classified as direct financial compensation whereas family and medical leave, social security, healthcare, life insurance, retirement plan, \& stock option are part of indirect financial compensation. From previous thoughts it can be concluded that compensation is a form of appreciation or reward in form of financial or nonfinancial from the company for the work that has been done by their employees.

Company need to carefully set up its compensation packages. We understand the importance of compensation both for employee and organization. Attractive compensation program can attract and retain outstanding employees. In some degree compensation also prove to increase employee loyalty and even their performance. Competitive compensation can provide company with advantages in terms of their ability to keep good performers. Some positive effects of attractive compensation are decrease in employee stress (Danish et al., 2015) and turnover intention (Tran, 2016). Pay satisfaction also believed to have positive impact on organizational commitment (Dhawan \& Mulla, 2011; Llanos \& Ahmad, 2017), motivation (Ferreira \& Badya, 2016; Gungor, 2011), job satisfaction (Salisu et al., 2015; Singh \& Loncar, 2010), employee performance (Darma \& Supriyanto, 2017; Thaief et al., 2015), employee loyalty (Manurung, 2017; Onsardi et al., 2016), and employee productivity (Yamoah, 2013). 
Figure 1 summarized those outcomes.

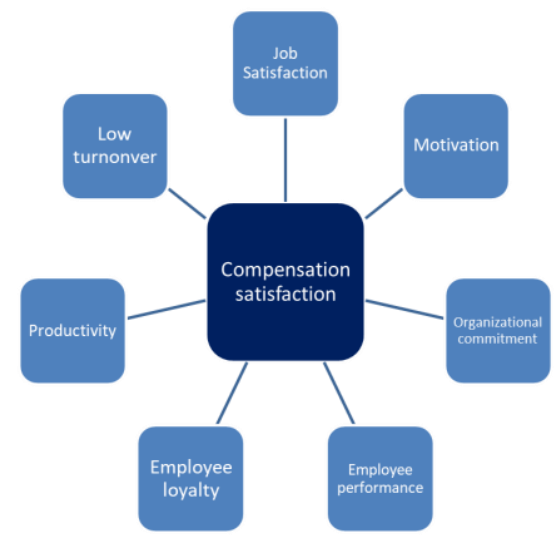

Figure 1. Outcomes of Compensation satisfaction

Managing compensation is not easy. Government regulation, external and internal justice, economics growth, availability of candidate, and costs (recruit and salary) are some of important aspects that should be considered by company. Basically, the purpose of developing attractive compensation for employee is to help company to achieve their objectives. But in doing so, the company should also focus on the employee's expectation.

\subsection{Work Stress}

Job stress is one of an important subject of study in human resource management and various definitions of work stress have been put forward by the organizational behavior experts. Stress defined as a dynamic condition where individual faced with various opportunities, demands, or resources which closely related with their interest but the outcomes is still uncertain. This uncertainty can cause psychological inconvenientand could influenced employee behavior at work. Stress also considered as the tension which appeared from extraordinary demands, constraints, or opportunities (Schermerhorn, et al., 2012). Stress has two parts, stress which has positive impact on attitude and performance (eustress) and the one with negative impact on both attitudes and performance (distress). Furthermore, Kinicki \& Fugate (2016) define stress as an adaptive response to environmental demands, referred to as stressors, that produce adaptive responses that include physical, emotional, and behavioral reactions that are influenced by individual differences. Stress can means different things to different people and can be described as feeling tense, anxious, or worried as they response to perceived threat that can have both positive and negative results (Gibson et al., 2012).

Gibson et al. (2012) explained three categories of stressor; individual level, organizational level, group level, and non-work condition. Job demands, role conflict, job security, organizational change are stressors which come from individual level. Different individual react differently to this stressors. On group level the stressors can include intragroup conflict, leadership style, and lack of cohesiveness. Culture incompatibility, lack of feedback, office politics, and lack of career development are part of organizational stressors. Meanwhile, factors not related with work or organization can also create stress. Economy status, family member, quality of life, commuting time are several things that can escalate stress level 


\section{Macrothink}

International Journal of Human Resource Studies

ISSN 2162-3058 2019, Vol. 9, No. 2

(Gibson et al., 2012; Kinicki \& Fugate, 2016). Various literatures identify antecedents of stress such as leadership style (Al-Hosam et al., 2016; Gill et al., 2010), role conflicts (Sheraz et al., 2014), work family conflict (Chiang et al., 2010), perceived organizational support (Wolff et al., 2016), motivation (Wani, 2013), job demands, career developments, and private lives (Schermerhorn et al., 2012).

Stress also has consequences both on individual and organization. Schermerhorn et al. (2012) described the consequences of stress in the workplace. Employees with too much stress and work overload could experience a break down in physical and mental systems. Robbins \& Judge (2017) mention several consequences of stress including illness, health conditions, anxiety, low emotional well-being, low job satisfaction, low job performance, high absenteeism and turnover. Gibson et al. (2012) and Kinicki \& Fugate (2016) agree that stress can result in forms of attitudinal, behavioral, cognitive, and physiological outcomes. Previous literatures found that stress can result in low job satisfaction (Malik et al., 2010a; Tziner et al., 2015; Duraisingam et al., 2009), higher turnover intention (Elci et al., 2012; Javed et al., 2014; Anton, 2009), lower organizational commitment (Cicei, 2012; Garg \& Dhar, 2014), hinder employee motivation (Kumar \& Varma, 2017), employee performance (Shahid et al., 2011; Gharid et al., 2016; Khuong \& Yen, 2016), and employee productivity (Charity, 2016; Ekienabor, 2016). The consequences of stress are presented in Figure 2.

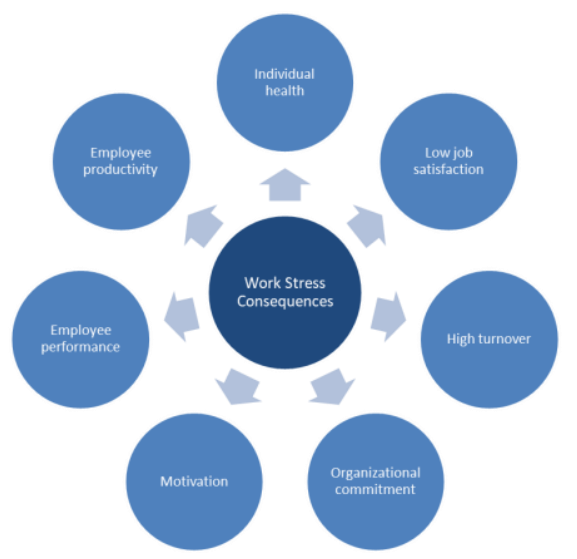

Figure 2. Work Stress Consequences

Negative effect from distress employees will harm organization. Stressful employees will make more mistakes, experience higher rate of work accident, conduct unethical behavior, and absenteism. Those can affect the service level which in the end reduce the capability to win the competition. In short, stressful employees will affect profitability, productivity, effectiveness, and efficiency of organizations. It is important to notice this condition and develop an array of solutions to prevent further damages. Organization needs to offer new approach to help employee reducing or managing their stress.

\subsection{Job Satisfaction}

Job satisfaction is a form of emotional and attitudinal response from employees towards their job. Gibson et al (2012) regards job satisfaction as an expression of individuals regarding 
their level of well-being associated with the work-load and activities. Job satisfaction defined by Luthans (2011) as the presence of positive feelings or happiness generated by the individual's assessment of their job or the results of employee perceptions to the extent of which the work has fulfilled their expectation. Employees with high levels of job satisfaction usually show positive behavior such as high attendance rates, low turnover, high concentration on their job, more diligent, manage effectively, serious at work, higher involvement, and will do the extra mile to serve customers. Job satisfaction have five dimensions; supervisor, career, salary, coworkers, and the job itself (Robbins \& Judge, 2017) which often used to measure the employee job satisfaction level. This satisfaction emerge from continous evaluation regarding thoses aspects.

Various variables attributed as causative factors of job satisfaction. Perception of conformity with organizational culture strongly correlated with job satisfaction in electronic and banking organization (Hsu, 2009; Dirani, 2009). Other elements that can also positively affect satisfaction include transformational leadership style (Rothfelder et al., 2013; Men, 2014), perceived organizational support (Lambert \& Hogan, 2009; Al-Hussami, 2008), work-life balance (Malik et al., 2010b), reward satisfaction (Jehanzeb et al., 2012), motivation (Gillet et al., 2013), organizational justice (Sieger et al., 2011), and organizational commitment (Masihabadi et al., 2015). Meanwhile, work stress also found to have relationship with job satisfaction but in an inverted form (Venkataraman \& Ganapthi, 2013; Giauque et al., 2013; Jaramilo et al., 2006). That is increased stress levels can reduce job satisfaction. Negative relation also found on the relation between work life conflict and job satisfaction. Employee experience higher incompatibility between work and family tend to have lower job satisfaction. Satisfied employee will perform better and contribute more to achieve organization goals. It is important for any organization to identify crucial factors which affect job satisfaction. By identifying such factors they can apply appropriate action.

Many benefits obtained by the organization when their employees perceive their job is satisfying. Prasetio et al. (2017) found the positive correlation between job satisfaction and organizational citizenship behavior. Satisfied employee willing to go the extra mile for the organization interests like helping co-workers, representing organization, and defend the organization image. Other positive impact from job satisfaction are the increase customer satisfaction and loyalty (Gibson et al., 2012), employee loyalty (Onsardi et al., 2016), motivation (Stringer et al., 2011), productivity, work safety, mental health, performance (Darma \& Supriyanto, 2017), affective commitment (Tosun \& Ulusoy, 2017). Managers can nurture satisfying work environments to fuel employees' job involvement (Kinicki \& Fugate, 2016). Beside the positive consequences, job satisfaction can have negative impact. If employee perceive that their job is not make them satisfy they might develop intention to leave (Singh \& Loncar, 2010). Employee also have problem with absenteism if they didnot like their job (Gibson et al., 2012; Yang, 2010). The negative impat felt by the organization can be in form of ineffectivity (Yang, 2010). Adding to the negative outcomes Kinicki \& Fugate (2016) argue that employee could develop counterproductive work behavior if they feel unsatisfied.

Realizing the effect that can cause organization in positive and negative ways, management 
should pay attention on how to foster interesting and satisfying job for their employees. Nowadays, employee not just go to work and do the job. They need to have positive and enrich work experience, work that challenge their knowledge and ability, which also give the employee to develop themselves. Responding to this growing demand, organization have to adjust their policy. All aspect that become vital for creating job satisfaction should manage properly. at first, it seems they only make employee happy. But in the long run, this policy will become fruitful for the organization.they will have outstanding human assets that will become their competitive advantages.

\subsection{Compensation and Work Stress}

Rewarding workers' efforts and recognising their organisational contributions and achievements as individuals and teams, are essential to minimising the risk of work-related stress (Workplace Health \& Safet QLD, 2014). Compensation consider as an important element that can influence employee behavior. Even though reward systems play a central role in the human resource management, their impact on stress was not well study and understood. This study will examine the role of compensation satisfaction on work stress experience by retail employee. Literatures which discuss compensation satisfaction and work stress were still limited. To complete the references material several articles that discuss effort-reward imbalance were included. Effort-reward imbalance (ERI) model claims that failed reciprocity in terms of high efforts spent by employees and low rewards received will likely to elicit recurrent negative emotions and sustained stress responses (Siegrist, 2012). ERI model suggest that when employees' perceptions of the rewards do not match their perceptions of the effort made, this can create an imbalance that affects well-being and related behavior (stress for example). Such explanation has similarities with employee dissatisfaction in regard with compensation they received.

Study from Weyer et al. (2006) indicate the elevation risks of poor self-rated health in nursing staff characterized by high effort in combination with low reward. This condition worsened for nurses who exhibit a high level of work-related overcommitment. The imbalance between effort made and reward receive has negative mental and physical outcomes for an individual (Smith et al., 2005). Furthermore he suggests that an imbalance of effort and reward can be stressful to the individual because such an imbalance contradict basic norm of social exchange like reciprocity. Further study from Lee et al. (2014) found that effort-reward imbalance model appears to capture the magnitude of the musculoskeletal health risk among nurses associated with job stress.

Regarding pay satisfaction, Danish et al. (2015) argued that job stress and pay satisfaction are moderately negatively correlated with each other. Employees who feel dissatisfied with their income tend to have higher stress levels. Meanwhile, Manyamba \& Ngezi (2017) confirm that the reduction of ERI can lower the stress level in hotel employees. From different point of view, Koch et al. (2017) reveal that there was a significant increase in burnout with an increase in ERI ratio. Lastly, still from ERI model, Rehman et al. (2010) found a high percentage of teachers with both job stress and dissatisfaction and an imbalance characterized by high effort and low reward in their professional life. This study clearly mention that 
reward in terms money and recognition have negative relation with stress. That is if employee perceive thair reward is adequate they will develop less work stress. Therefore, for hypothesis H1 this study propose;

\section{$H_{1}$ : compensation satisfaction will have significant and negative effect on work stress.}

\subsection{Compensation and Job Satisfaction}

Job satisfaction has known for its important in shaping employee attitude and become an interesting area in organizational behavior study. Recently, more scholars focused to examine the elements of job satisfaction and factors that affect it. One factors which believed to affect satisfaction is compensation. Basically, compensation is a means for employees to satisfy their need. In the end employee will receive salaray, benefit, compensation in return for his employment, the importance of pay and benefit in satisfying the economic need of employees should always be a concern for organization. This statement has been supported by many writers from various cultural background. Furnham et al. (2009) in United Kingdom claimed that previous research found that job satisfaction is linked with the monetary compensation and non-monetary payment. Even though money is not the only thing that matters when organization need to enhance job satisfaction many scholars conducted study which involving these variables. Study using participants from insurance sector in Nigeria found positive relation between compensation and job satisfaction (Adeoye \& Fields, 2014). Previous research from United States, Vietnam, and Malaysia found positive correlation between employee recognition, pay, and benefit with job satisfaction (Tessema et al., 2013).

Employee satisfaction is key success factor for business organization and it can be enhanced by providing more autonomy, reducing work stress, and provide attractive compensation package (Whitt, 2006). Various dimensions of compensation like pay, benefits, incentives known to have a positive correlation toward job satisfaction (Butt et al., 2007; Gelard \& Rezaei, 2016; Danish et al., 2015; Mabaso \& Dlamini., 2017). Studies from Pakistan and Ghana (Pepra-Mensah et al., 2017; Hina et al., 2014) were also included to expand the diversity of the study on the relationship between compensation and job satisfaction. Those results suggest that if compensation satisfaction increases, job satisfaction tend to increase and vice versa. Studies which contribute to the understanding of the relationships between both variables and found positive relation were Malik et al. (2010b), Salisu et al. (2015), Jehanzeb et al. (2012), Usman et al. (2016), Onsardi et al. (2016), Darma \& Supriyanto (2017), Vidal et al. (2007), Singh \& Loncar (2010).

Although most studies show a positive relationship, there are different results like from Terera \& Ngirande (2014) who found there is no association between rewards and job satisfaction. Charith (2015) also found a low correlation regarding job satisfaction and fringe benefits, which indicate that fringe benefit is not important to job satisfaction of an employee. Since there are different results, future study need to conduct more research to explore these contradictory finding. Besides, it is still important to always make employee enjoying their job to boost morale and icnrease productivity. Although there are contradictions from some research results, most previous research regarding compensation and job satisfaction shows significant positive relations. Therefore the second hypothesis is; 
$\mathrm{H}_{2}$ : compensation will have significant and positive effect on employee job satisfaction.

\subsection{Work Stress and Job Satisfaction}

Transactional model of stress introduced by Folkman \& Lazarus stated that the individual level of stress is determined by how that individual cognitively assess the events or conditions they faced (Ganster et al., 2011). Exposure to some disturbing and unwanted working condition individuals could assume whether such conditions represent as a threat or as a challenging. If they chose the later, then usually they easily adjust their mental state to new challenges. But, if they perceive as threat they will assess their ability to cope with it. Distress happen when they perceive that they cannot cope with this threat. Besides being a major contributor to both mental and physical health problems, stress at work also decrease performance and productivity. Employees who experience high stress levels are difficult to achieve his target because they feel bad about the job.

Trivellas et al. (2013) conducted study in Greek hospital using 271 nurse and found the negative effect of work stress on job satisfaction. Study using 200 public service in Iran also reveal the same finding (Bemana et al., 2013). From western culture, Lambert \& Paoline III (2008) examine 1062 correctional staffs in Florida and support the reverse correlation between work stress and job satisfaction. There are many studies that has been done in various industries and countries regarding the relation of stress and job satisfaction. Studies that support the negative relation were from Masihabadi et al. (2015) using 170 auditor in Iran, Malik, et al. (2011) using 105 transportaion hostesses in Pakistan, Venkataraman \& Ganapthi (2013) in small scale organization in India with 300 participants, Tziner et al. (2015) in Israel with 124 staff as participants, Duraisingam et al. (2009) in Australia with 369 participants, Kumar \& Varma (2017) using 96 bank managers in India, Jaramillo et al. (2006) who examine 138 retail sales staffs in United states of America, Lu et al. (2017) using 930 health worker in China, and Danish et al. (2015) in Pakistan. Those scholars argue that the higher stress level experience by the employee, they tend to develop lower job satisfaction. Besides those individual study, Zangaro \& Soeken (2007) conducted meta-analysis on the relation of work stress and job satisfaction and found strong negative correlation.

Although most of previous literatures suggest significant negative effect, but there were also studies which reveal that work stress didnot have significant relation with job satisfaction. Studies from India, Iran, and Pakistan found that stress is not significantly affecting the job satisfaction. Those studies using various participants like teacher (Usman et al., 2016), hospital staff (Kafashpoor et al., 2014), and various organization (Nahar et al., 2013). Considering that most of the findings support the existence of significant and positive relationships, this study determines the following hypothesis;

$H_{3}$ : work stress will have significant negative effect on employee job satisfaction.

Regarding the mediation analysis, there is a study that examines the mediation role of work stress. But the independent variable was work-family conflict. But at least this can be the basis of the mediating work stress in relationships compensation satisfaction and job satisfaction. The next hypothesis is: 


\section{Macrothink}

International Journal of Human Resource Studies

ISSN 2162-3058 2019, Vol. 9, No. 2

$H_{4}$ : work stress will have significant and negative mediation effect in the relation of compensation satsfaction and employee job satisfaction.

\section{Methodology}

\subsection{Participants}

The participants were 107 participants from a national retail establishment operate in Samarinda and consist of 102 officers and 5 supervisors. Questionnaire given to 146 employees and a total of 107 usable responses were returned, yielding a response rate of 69.9\%. This response rate was cconsidered high and fortunately there was no any missing data. The method of determining this sample is used considering the difficulties to meet the participants. In this case we distribute the questionnaire to all employees and set the deadline for them to return the response. Such method has often been used in organizational behavior research (Jaramillo et al., 2006 and Trivellas et al., 2013). Participants profile are explained in several categories. The gender ratio of the participants was $67 \%$ men and $33 \%$ women. $69 \%$ of them are under 25 years old, it is common for a retail store who employe younger worker. Most participants were unmarried (72\%) and educated mostly to high school degree level $(81 \%)$. Regarding tenure, $46 \%$ has worked between 1 to 3 years. It is also common for retail industry which have high turnover. Surprisingly, 65\% work not more than 9 hours a day which is a pretty unique thing for a retail. Detail description provided in Table 1.

Table 1. Participants

\begin{tabular}{cccc}
\hline Demographics & Classification & No of Participants & Percentage \\
\hline \multirow{2}{*}{ Gender } & Male & 72 & $67 \%$ \\
& Female & 35 & $33 \%$ \\
Age & $<25$ & 74 & $69 \%$ \\
& $25-30$ & 28 & $26 \%$ \\
& $>30-35$ & 5 & $5 \%$ \\
Marital & Married & 30 & $28 \%$ \\
& Single & 77 & $72 \%$ \\
& Divorced & 0 & $0 \%$ \\
\multirow{5}{*}{ Tenure } & $<1$ year & 26 & $24 \%$ \\
& $1-3$ year & 46 & $43 \%$ \\
& $>3-5$ year & 26 & $24 \%$ \\
Position & $>5-10$ year & 9 & $8 \%$ \\
& Officer & 102 & $95 \%$ \\
& Supervisor & 5 & $5 \%$ \\
Having Child & Yes & 27 & $25 \%$ \\
& No & 80 & $75 \%$ \\
& High School & 87 & $81 \%$ \\
& Diploma & 6 & $6 \%$ \\
Work Hour & Under Graduate & 14 & $13 \%$ \\
& up to 9 Hours /day & 70 & $65 \%$ \\
& $>9$ Hours /day & 37 & $35 \%$ \\
\hline
\end{tabular}

3.2 Data Analysis 
Analyses included descriptive statistics, correlations and regressions and factor analysis. Assumptions to normality was not needed since the study use bootstrapping approach which is considered appropriate to determine the influence between variables as well as determining the existence of an element of mediation (Preacher et al., 2007). The same ideas also delivered by MacKinnon et al. (2004) who argue that through the computation of bootstrapped confidence intervals we can avoid some problems due to asymmetric and other non-normal sampling distributions of an indirect effect. Sekaran \& Bougie (2016) confirmed this idea and state that bootstrapping is a statistical method based on building a sampling distribution for a statistic by resampling from the data at hand. A big advantage of bootstrapping is that no assumptions about the shape of the sampling distribution of the statistic are necessary when conducting inferential tests. SPSS with Process was used to conduct the regression and mediation. Process is macro adds-on for SPSS develop by Hayes (2013). The mediation role of a variable (work stress in this case) will be determined based on the value of the Upperlevel and Lowerlevel Confidence Interval. Both values should not contain the number 0 .

\subsection{Measurement}

Compensation satisfaction measure using 25 items develop by Hasibuan (2012) which consist of direct $\&$ indirect compensation. The instrument was designed to assess the extent to which employees perceived their compensation. Participants were asked to indicate how satisfy their compensation using a six-point scale ( 1 very dissatisfied, 6 very satisfied). The Cronbach's alpha is .885 . Example of the items are 'basic salary I receive can meet my daily needs' and 'organization provides adequate health insurance'.

Work stress was measured using the scale developed by Elci et al. (2012). It consist of 8 items. Participants asked to indicate how they perceive work stress. Same as previsou variable, it is also using six-point scale. The Cronbach's alpha is .897. Example of items are 'job demands take a lot of my time \& energy' and 'the job is not in accordance with my knowledge \& abilities'.

Job satisfaction was measured with twenty items adapted from Robbins \& Judge (2017). A six-point response scale was employed rangeing from 1 - strongly agree to 5 strongly disagree. The Cronbach's alpha is .845. Example of items are 'provide the opportunity to do various jobs' and 'my job provide clear promotional opportunities'.

\section{Result and Discussion}

\subsection{Result}

Table 2 showed the correlation between variables and also demographic aspect. Correlation between compensation and work stress is not significant. But compensation show significant in positive direction with job satisfaction. While work stress and job satisfaction also had significant relation but in reverse direction (negative). Employee's age had positive correlation with education, tenure, and position. Which mean older employees tend to had higher education, longer tenure, and high position. This is normal in a business organization. Older employee can be assumed that they work longer and usually given a managerial 
position compare to the new one. Education also had positive correlation with position which explain that for higher level position, organization will put individual with higher education level. The interesting findings are that employee with higher education and longer tenure perceived that their compensation increasingly inappropriate with their profile. They perceive that thei rcompensation is less than they expected. Finally, the work hour of higher level position was related with more work hours. In retail business this is normal. Supervisor and manager usually stay quite late to prepare daly report and to evaluate their achievement for today.

Table 2. Mean, Standard Deviation, \& Correlation

\begin{tabular}{|c|c|c|c|c|c|c|c|c|c|c|c|}
\hline & Mean & $\begin{array}{c}\text { Std. } \\
\text { Deviation }\end{array}$ & $\mathbf{N}$ & Age & Education & Tenure & Position & Workhour & Compensation & Stress & $\begin{array}{c}\text { Job } \\
\text { Satisfaction } \\
\end{array}$ \\
\hline Age & 1.3551 & .57054 & 107 & 1 & & & & & & & \\
\hline Education & 1.3178 & 69497 & 107 & $.308^{* * *}$ & 1 & & & & & & \\
\hline Tenure & 2.1682 & .89533 & 107 & $.528^{* *}$ & .171 & 1 & & & & & \\
\hline Position & 1.0467 & .21205 & 107 & $.329^{* *}$ & $.282^{* *}$ & $.356^{* * *}$ & 1 & & & & \\
\hline Workhour & 1.3458 & .47786 & 107 & .030 & -.078 & .039 & $.211^{*}$ & 1 & & & \\
\hline Compensation & 3.4700 & .47907 & 107 & -.161 & $-.263^{* *}$ & $-.223^{*}$ & -.075 & .018 & 1 & & \\
\hline Stress & 3.1433 & .65584 & 107 & -.012 & -.099 & .052 & -.006 & .138 & -.063 & 1 & \\
\hline Job Satisfaction & 3.4468 & .54981 & 107 & -.106 & -.163 & -.033 & .047 & .108 & $.620^{* *}$ & $-.226^{*}$ & 1 \\
\hline
\end{tabular}

Regression coefficient shown in Table 3 confirmed that compensation satisfaction can not be used to preditc work stress $\left(\mathrm{p}>.05\right.$ ). Thus hypothesis $\mathrm{H}_{1}$ is not supported. On the other hand, compensation satisfaction can predict job satisfaction $(\mathrm{p}<.00)$, while work stress, even though it only shows a relatively small value (-.158), also affecting the job satisfaction ( $p$ $<.01)$. Therefore, hypothesis $\mathrm{H} 2$ and $\mathrm{H} 3$ are supported.

Table 3. Regression coefficient, Standard error, \& Model Summary

\begin{tabular}{lcccccc}
\hline & \multicolumn{3}{c}{ Stress } & \multicolumn{3}{c}{ Job Satisfaction } \\
& Coeff & SE & p-value & Coeff & SE & p-value \\
\hline Compensation & -0.086 & 0.133 & 0.522 & 0.698 & 0.086 & 0.000 \\
Stress & - & - & - & -0.158 & 0.063 & 0.014 \\
Constant & 3.440 & 0.467 & 0.000 & 1.520 & 0.370 & 0.000 \\
\cline { 2 - 7 } & \multicolumn{2}{c}{ R Square } & 0.004 & R Square & 0.648 \\
& \multicolumn{2}{c}{$\mathrm{F}=$} & 0.412 & \multicolumn{2}{c}{$\mathrm{F}=$} & 37.561 \\
$\mathrm{p}=$ & 0.522 & $\mathrm{p}=$ & 0.000 \\
\hline
\end{tabular}

Next discussion is analyze the mediating role of work stress in relationships of compensation and job satisfaction. It was clear that compensation did not have relation or effect on work stress. Therefore, work stress surely can not mediate the relationship between compensation and job satisfaction. This is supported by the calculations obtained from Process presented in Table 4. The bootstrap confidence interval contain zero because the sign was shown negative in Lower Level and positive in Upper Level. Hayes (2013) and Preacher et al. (2007) a variable is believed to have a mediating role if the Upper Level and the Lower Level of bootstrap confidence interval did not contain zero value. That is hypothesis $\mathrm{H} 4$ was not supported, work stress did not mediate the relation between compensation and job 
satisfaction.

Table 4. Indirect Effect of Work Stress

Indirect Effect of Compensation on Job Satisfaction

\begin{tabular}{ccccc}
\hline & Effect & Boot SE & BootLLCI & BootULCI \\
\hline Through Stress & 0.014 & 0.031 & -0.038 & 0.093
\end{tabular}

Figure 3 presents the regression analysis obtain from Process and show that compensation and work stress had no relation. To summarize the findings of this study table 6 shows the results of hypothesis testing.

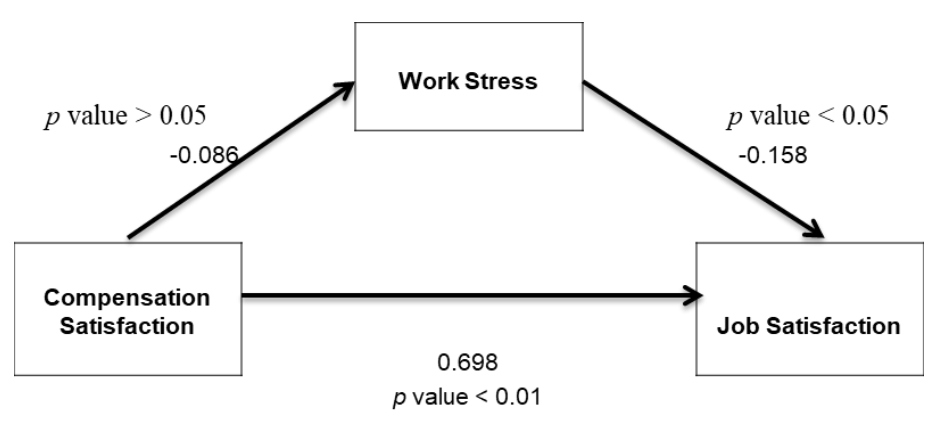

Figure 3. Mediation Model

Table 6. Hypothesis Summary

\begin{tabular}{clc}
\hline Hypothesis & \multicolumn{1}{c}{ Effect } & Result \\
\hline $\mathrm{H}_{1}$ & Compensation --> Work Stress & Not Supported \\
$\mathrm{H}_{2}$ & Compensation --> Job Satisfaction & Supported \\
$\mathrm{H}_{3}$ & Work Stress --> Job Satisfaction & Supported \\
$\mathrm{H}_{4}$ & Compensation --> Work Stress --> Job Satisfaction & Not Supported \\
\hline
\end{tabular}

\subsection{Discussion}

Using Indonesia retail company as a sample, the present study pioneering the study which investigates the relationship between perceived compensation satisfaction, work stress, and job satisfaction. This article was intended to enrich the knowledge in human resource management and organizationalo behavior. Specifically the discussion related to those variables. Previous research on work stress represent the negative relation from compensation satisfaction. Employees who perceive they have done more work but receive low rewards will likely to show negative emotions and sustained stress responses (Siegrist, 2012; Weyer et al., 2006; Smith et al., 2005; Lee et al., 2014; Danish et al., 2015; Manyamba \& Ngezi, 2017). Yet this study found that there are no relation between these variables. Most of previous studies discussed the imbalance between effort and reward which can be understand from the compensation dissatisfaction. The difference in the finding can be a contribution to the knowledge. This will give rise to new thinking that work stress is not related to satisfaction with compensation. It should be noted that this study conducted in Indonesia which known to have collective culture. In order to reduce the stress level, organization are not recommended 
to use their compensation. Instead they might look at the work design, the worker relation with each other or with their supervisor. In fact a study in several big cities in Indonesia in 2017 found that the biggest cause of stress was worker relation. The career advancement also can become major stress antecedent for certain individual. The finding and also the discussion of compensation and work stress will enrich the insight and concept regarding the construct. Currently, only a limited studies avaliable which comprehensively focus on compensation and work stress.

Consistent with most previous studies, our finding confirm that there is positive effect from compensation on job satisfaction. Thus reaffirm that compensation was one of the biggest influencer in developing job satisfaction. According to Furnham et al. (2009) monetary compensation and non-monetary payment linked with job satisfaction. Study from Nigeria also found positive relation between compensation and job satisfaction (Adeoye \& Fields, 2014). Those findings supported by the result from study based on various cultural background such as United States, Vietnam, and Malaysia (Tassema et al., 2013). Compensation that can meet employee needs can lift morale and increase job satisfaction. Theory of social exchange posits that human relationships are formed by the use of a subjective cost-benefit analysis and the comparison of alternatives. Ths theory frequently used in the business world to imply a two-sided, mutually contingent and rewarding process involving transactions or simply exchange, like between organization and employees or organization with customers. When individual felt rewarded they will repeat their action because of stimulus from past experience. They do it willingly without outisde pressure. Such condition made the individual happy in doing their part because they know they will get reward. So they keep doing it. One thing that should be noted is that organization must carefully indentify which compensation method they can apply. Similir and repetitive reward can decrease the reward value, which in the end does not help to build job satisfaction. Employee satisfaction must always be considered given the importance of job satisfaction associated with positive outcomes (performance, turnover, organizational commitment, and orgnizational citizenship behavior).

In corroboration with previous studies from Trivellas et al. (2013) in Greek, Bemana et al. (2013) in Iran, Lambert \& Paoline III (2008) in United States, Malik, et al. (2011) in Pakistan, Ganapthi \& Venkataraman (2013) in India, and Tziner et al. (2015) in Israel, work stress negatively impact job satisfaction. The differences between this study and the previous is the value of correlation. However, this affirm that distress can lead to less satisfied employee. Many factors affecting employee stress level. Work stress can not be avoid instead employee must dealt with it. Organization role is to help employee to overcome their stress so id does not develop into more negative outcomes. Even though the company has provided support, it is undeniable that most stress arises from within employees. Personal traits of each employee paly important and crucial part to lessen the stress level. Several action that can be implemented by organization are create positive work environment where everyone can do their job without unnecessary interuption, provide leadership style that match employee preference, conduct routine interaction to allign work-related perspective, and in this case, for retail company, provide flexible work hour that can be arrange between employee and their 
co-workers, provide more advance system which can prevent theft and loss, giving extra paid leave for certain condition, and as usual provide counselling in the work premise.

Our findings provide useful guidance for retail organization which try to enhance job satisfaction of their employees. The old paradigm that compensation can heal everything seems no longer valid. Work stress is not related with compensation, so they have to find what is matter which can reduce employee's stress level. One thing is certain that compensation can and still become better prediction of job satisfaction. Although compensation can not influence work stress, at least the right combination of attractive package can enhance job satisfaction. But, relying only on one aspect can harm organization. Especially regarding the use of compensation which believe only have short impact. Therefore, human resource department in this organization should thoroughky conduct study to identify other factors which can be use to develop job satisfaction.

The present study gave new perspectives for practitioners and researchers regarding job satisfaction in a retail organization. However, several limitation still need to be considered. The use of one branch lower the chance to generalzed the result. Further study should, if possible, use several branches from different part of Indonesia. Next, cross-sectional data difficult confirm the direction of causality implied in our research model since only conducting survey in one time frame. Longitudinal studies are needed to validate the predictive dimension of the model by examining actual satisfaction over several time frame. After all, satisfaction and work stress are individual's perception that changing overtime. Further study can use structura equation model to analyze the variable in more depth and detail. Finally, new research could examine a wider variety of job satisfaction antecedents like work-life balance, leadership style, pereive organizational support, organization culture, employee persoanlity, and career enhancement.

\section{Conclusion \& Recommendation}

Retail industry facing tremendous challenges. This is indicated by increasing number of new stores from competitors, the emergence of new regulation from government, and recently they also hit by new business of e-commerce. As a result, they have to deal with decreasing customer and also to find new approach to keep the business. One of their strength lies in their human resources. They need to be able to make them enjoy what they do. It is important to make employees experience high job satisfaction. The result of the study hopefully will benefit the organization in helping them to find the right option to boost employee job satisfaction.

Hypothesis testing reveal that compensation didnot affect work stress, $\mathrm{H}_{1}$ was not supported. Employee stress level didnot have anything with their compensation. However, the second hypothesis $\mathrm{H}_{2}$ was supported. We have found that employees consider compensation satisfaction as important factors that enhance their job satisfaction. That is why it is recommended that employers offer attractive compensation packages (salary, benefit, and others) to their employees. The third hypothesis also supported, that employee stress level will have impact on the perception toward job satisfaction. Although only rpresent a small value, organization need to pay attention to what can increase employee stress level. Finally, 
since compensation and work stress did not have relation, accordingly the hypthesis $\mathrm{H}_{4}$ was rejected. Work stress did not mediate the relation between compensation and job satisfaction. From the results it is also recommended that organizations should introduce new compensation system for employee with higher education level and longer tenure. It seems they perceive their compensation was not fit with their background. Management should find out and solve this problem.

Organization are advised to conduct further studies to identify other aspects which might have strong correlation with job satisfaction such as work-life balance, leadership style, working condition, and person-job fit. These variables can be explored to enhance the human resources practice which aim to increas employee's job satisfaction. If achieved, then they can rely on their human resource as the competitive advantage for their business.

\section{Acknowledgement}

I would like to thank Program Bantuan Seminar Luar Negeri, Ditjen Penguatan Riset dan Pengembangan, Kemenristekdikti for providing this development program and allow me to attend and present my academic articles in the conference.

\section{References}

Adeoye, A. O., \& Fields, Z. (2014). Compensation Management and Employee Job Satisfaction: A Case of Nigeria. Journal of Social Sciences, 41(3), 345-352. https://doi.org/10.1080/09718923.2014.11893369

Alcover, C., Chambel, M. J., Fernandez, J. J., Rodriguez, F. (2018). Perceived organizational support-burnout-satisfaction relationship in workers with disabilities: The moderation of family support. Scandinavian Journal of Psychology, 1-13. https://doi.org/10.1111/sjop.12448

Al-Hosam, M. A. A., Ahmed, S., Ahmda, B. F., \& Joarder, R. H. M. (2016). Impact of Transformational Leadership on Psycological Empowerment and Job Satisfication Relationship: A Case of Yemeni Banking. Binus Business Review, 7(2), 109-116. https://doi.org/10.1111/sjop.12448

Al-Hussami, M. (2008). A Study of Nurses' Job Satisfaction: The Relationship to Organizational Commitment, Perceived Organizational Support, Transactional Leadership, Transformational Leadership, and Level of Education. European Journal of Scientific Research, 22(2), 286-295.

Antón, C. (2009). The impact of role stress on workers' behaviour through job satisfaction and organizational commitment. International Journal of Psychology, 44(3), 187-194. https://doi.org/10.1080/00207590701700511

Aydogmus, C., Camgoz, S. M., Ergeneli, A., \& Ekmekci, O. T. (2017). Perceptions of transformational leadership and job satisfaction: The roles of personality traits and psychological empowerment. Journal of Management \& Organization, 1 of 27. https://doi.org/10.1017/jmo.2016.59

Azeem, S. M., \& Akhtar, N. (2014). Job Satisfaction and Organizational Commitment among 
Public Sector Employees in Saudi Arabia. International Journal of Business and Social Science, 5(7), 127-133. https://doi.org/10.6007/IJARBSS/v5-i12/1943

Butt, B. Z., Rehman, K. U., \& Safwan, N. (2007). A Study Measuring the Effect of Pay, Promotion and Training on Job Satisfaction in Pakistani Service Industry. European Journal of Social Sciences, 5(3).

Cass, M. H., Siu, O. L., Faragher, E. B., \& Cooper, C. L. (2003). A meta-analysis of the relationship between job satisfaction and employee health in Hong Kong. Stress and Health, 19(2). https://doi.org/10.1002/smi.959

Charith, B. (2015). Impact of Fringe Benefits on Job Satisfaction in Mining and Construction Companies in India. International Journal of Marketing and Human Resource Management, 6(3), 46-67.

Charity, E. (2016). Impact of Stress on Employee's Productivity in Financial Institutions in Nigeria. European Journal of Business and Management, 8(19), 105-109.

Chiang, F. F. T., Birtch, T. A., \& Kwan, H. K. (2010). The moderating roles of job control and work-life balance practices on employee stress in the hotel and catering industry. International Journal of Hospitality Management, 29, 25-32. https://doi.org/10.1016/j.ijhm.2009.04.005

Choi, S. E., \& Kim, S. D. (2016). A meta-analysis of the variables related to job satisfaction among Korean nurses. Contemporary Nurse. https://doi.org/10.1080/10376178.2016.1221736

Cicei, C. C. (2012). Occupational Stress and Organizational Commitment In Romanian Public Organizations. Social and Behavioral Sciences, 33, 1077-1081. https://doi.org/10.1016/j.sbspro.2012.01.288

Danish, R. Q., Shahid, A. U., Aslam, N., \& Ali, A. (2015). The Impact of Pay Satisfaction and Job Stress on Job Satisfaction in Pakistani Firms of Gujranwala District. American Journal of Economics, Finance and Management, 1(3), 207-210.

Darma, P. S., \& Supriyanto, A. S. (2017). The Effect of Compensation on Satisfaction and Employee Performance. Management and Economics Journal, 1(1), 69-78. https://doi.org/10.18860/mec-j.v1i1.4524

Dessler, G. (2013). Human Resource Management, 13th ed. New Jersey: Pearson.

Dewi, N. K. (2014). Analysis: Retail overview: Huge opportunity amid tight competition. http://www.thejakartapost.com/news/2014/10/29/analysis-retail-overview-huge-opportunity-a mid-tight-competition.html. Accessed November 28, 2018.

Dhawan, V., \& Mulla, Z. R. (2011). The role of pay and leadership in developing organizational commitment. South Asian Journal of Management, 18(2), 60-75.

Dirani, K. M. (2009). Measuring the learning organization culture, organizational commitment and job satisfaction in the Lebanese banking sector. Human Resource Development International, 12(2), 189-208. https://doi.org/10.1080/13678860902764118 
Duraisingam, V., Pidd, K., \& Roche A. M. (2009). The impact of work stress and job satisfaction on turnover intentions: A study of Australian specialist alcohol and other drug workers. Drugs: education, prevention and policy, 16(3), 217-231. https://doi.org/10.1080/09687630902876171

Ekienabor, E. E. (2016). Impact of Job Stress On Employee Productivityand Commitment. International Journal for Research in Business, Management and Accounting, 12(5), 124-133.

Elci, M., Sener, I., Aksoy, S., \& Alpkan, L. (2012). The Impact of Ethical Leadership and Leadership Effectiveness on Employees' Turnover Intention: The Meditating Role of Work Related Stress. Procedia - Social and Behavioral Sciences, 58, 289-297. https://doi.org/10.1016/j.sbspro.2012.09.1003

Ferreira, D., \& Baidya, T. K. (2016). The Impact Of Compensation Systems On The Motivation Of Teachers Of A Higher Education Institution. International Journal Of Business Management and Economic Research (IJBMER), 7(6), 793-803.

Furnham, A., Eracleous, A., \& Chamorro-Premuzic, T. (2009). Personality, motivation and job satisfaction: Hertzberg meets the Big Five. Journal of Managerial Psychology, 24(7-8), 765-779. https://doi.org/10.1108/02683940910996789

Ganster, D. C., Kiersch, C. E., Marsh, R. E., \& Bowen, A. (2011). Performance-Based Rewards and Work Stress. Journal of Organizational Behavior Management, 31, 221-235. https://doi.org/10.1080/01608061.2011.619388

Garg, S., \& Dhar, R. L. (2014). Effects of stress, LMX and perceived organizational support on service quality: Mediating effects of organizational commitment. Journal of Hospitality and Tourism Management, 21, 64-75. https://doi.org/10.1016/j.jhtm.2014.07.002

Gelard, P., \& Rezaei, S. (2016). The Relationship between Job Motivation, Compensation and Job Satisfaction in Employees of Tax Administration - A Case Study in Tehran. Asian Social Science, 12(2), 165-171. https://doi.org/10.5539/ass.v12n2p165

Gharid, M., Ghouse, S. M., \& Ahmad, M. (2016). The impact of job stress on job performance: A case study on academic staff at Dhofar University. International Journal of Economic Research, 13(1), 21-33.

Giauque, D., Anderfuhren-Biget, S., \& Varone, F. (2016). Stress and turnover intents in international organizations: social support and work-life balance as resources, The International Journal of Human Resource Management. https://doi.org/10.1080/09585192.2016.1254105

Gibson, J. L., Ivancevich, J. M., Donnelly Jr., J. H., \& Konopaske, R. (2012). Organizations: Behavior, Structure, Processes, $14^{\text {th }}$ edition. New York: McGraw-Hill.

Gill, A., Flashchaner, B. A., \& Bhutani, S. (2010). The Impact of Transformational Leadership and Empowerment on Employee Job Stress. Business and Economics Journal, 3.

Gillet, N., Gagné, M., Sauvagère, S., \& Fouquereau, E. (2013). The role of supervisor 
autonomy support, organizational support, and autonomous and controlled motivation in predicting employees' satisfaction and turnover intentions. European Journal of Work and Organizational Psychology, 22(4), 450-460. https://doi.org/10.1080/1359432X.2012.665228

Gomez-Mejia, L. R., Balkin, D. B., \& Cardy, R. L. (2012). Managing Human Resources, 7th Edition. USA: Pearson.

Griffin, R. W., \& Moorhead, G. (2014). Organizational Behavior Managing People and Organizations. South Western: Cengage Learning.

Güngör, P. (2011). The Relationship between Reward Management System and Employee Performance with the Mediating Role of Motivation: A Quantitative Study on Global Banks. 7th International Strategic Management Conference, Procedia Social and Behavioral Sciences, 24, 1510-1520. https://doi.org/10.1016/j.sbspro.2011.09.029

Hasibuan, M. (2012). Manajemen Sumber Daya Manusia (Edisi Revisi ed.). Jakarta: Bumi Aksara.

Hayes, A. F. (2013). Introduction to Mediation, Moderation, and Conditional Process Analysis: A Regression-Based Approach. New York: The Gilford Press.

Hina, Q., Zamir, S., \& Nudrat, S. (2014). Impact of Employee Benefits on Job Satisfaction of Teachers at Higher Level. Journal of Education and Practice, 5(7), 122-129.

Hsu, H. Y. (2009). Organizational Learning Culture's Influence on Job Satisfaction, Organizational Commitment, and Turnover Intention among $R \& D$ Professionals in Taiwan during an Economic Downturn. University of Minnesota, Dissertattion.

Jaramillo, F., Mulki, J., \& Solomon, P. (2006). The Role of Ethical Climate on Salesperson's Role Stress, Job Attitudes, Turnover Intention, and Job Performance. Journal of Personal $\begin{array}{llllll}\text { Selling } \quad \text { and } & \text { Sales } & \text { Management, } & 26(3), & 271- & 282 .\end{array}$ https://doi.org/10.2753/PSS0885-3134260302

Javed, M., Khan, M. A., Yasir, M., Aamir, S., \& Ahmed, K. (2014). Effect of Role Conflict, Work Life Balance and Job Stress on Turnover Intention: Evidence from Pakistan. Journal of Basic and Applied Scientific Research, 4(3), 125-133.

Jehanzeb, K., Rasheed, F. M., Rasheed, A., \& Alamzeb, A. (2012). Impact of Rewards and Motivation on Job Satisfaction in Banking Sector of Saudi Arabia. International Journal of Business and Social Science, 3(21), 272-278.

Kafashpoor, A., Sadeghian, S., Shakori, N., \& Kavoosi, S. (2014). The Impact of Job Stress on Turnover Intention Mediating Role of Job Satisfaction and Affective Commitment; Case Study: Mashhad's Public Hospitals. Applied mathematics in Engineering, Management, and Technology, 2(1), 96-102.

Karadag, E. (ed) (2015). Leadership and Organizational Outcomes Meta-Analysis of Empirical Studies. Switzerland: Springer.

Khuong, M. N., \& Yen, V. H. (2016). Investigate the Effects of Job Stress on Employee Job 
Performance - A Case Study at Dong Xuyen Industrial Zone, Vietnam. International Journal of Trade, Economics and Finance, 7(2), 31-37. https://doi.org/10.18178/ijtef.2016.7.2.495

Kinicki, A., \& Fugate, M. (2016). Organizational Behavior: A Practical Prolem Solving Approach. New York: McGraw-Hill.

Koch, P., Kersten, J. F., Stranzinger, J., \& Nienhaus, A. (2017). The effect of effort-reward imbalance on the health of childcare workers in Hamburg: a longitudinal study. Journal of Occupational Medicine and Toxicology, 12(16). https://doi.org/10.1186/s12995-017-0163-8

Kumar, R., \& Varma, B. (2017). Study of Job Satisfaction in Relation to Work Motivation and Occupational Stress among Bank Managers. The International Journal of Indian Psychology, 4(4), 164-174.

Lambert, E. G., \& Paoline III, E. A. (2008). The Influence of Individual, Job, And Organizational Characteristics on Correctional Staff Job Stress, Job Satisfaction, and Organizational Commitment. Criminal Justice Review, 33(4), 541-564. https://doi.org/10.1177/0734016808320694

Lambert, E., \& Hogan, N. (2009). The Issue of Support from Supervisors and Management in Shaping the Job Stress, Job Satisfaction, and Organizational Commitment of Private Correctional Staff. Journal of Applied Security Research, 4, 62-482. https://doi.org/10.1080/19361610903176286

Lee, S. J., Lee, J. H., Gillen, M., \& Krause, N. (2014). Job Stress and Work-Related Musculoskeletal Symptoms Among Intensive Care Unit Nurses: A Comparison Between Job Demand-Control and Effort-Reward Imbalance Models. American Journal of Industrial Medicine, 57, 214-221. https://doi.org/10.1002/ajim.22274

Llanos, L. F., \& Ahmad, R. (2017). Financial Compensation and Organizational Commitment: Differences Among Mexican and Malaysian Bankers. Compensation \& Benefits Review, 1-16.

Lu, Y., Hu, X. M., Huang, X. L., Zhuang, X-D., Guo, P., Feng, L-F., ... Hao, Y-T. (2017). The Relationship Between Job Satisfaction, Work Stress, Work-Family Conflict, and Turnover Intention Among Physicians in Guangdong, China: a crosssectional study. BMJ Open, 7, e014894. https://doi.org/10.1136/bmjopen-2016-014894

Luthans, F. (2011). Organizational Behavior. Singapore: McGraw Hill.

Mabaso, C. M., \&Dlamini, B. I. (2017). Impact of Compensation and Benefits on Job Satisfaction. Research Journal of Business Management, 11(2), 80-90. https://doi.org/10.3923/rjbm.2017.80.90

MacKinnon, D. P., Lockwood, C. M., \& Williams, J. (2004). Confidence limits for the indirect effect: Distribution of the product and resampling methods. Multivariate Behavioral Research, 39, 99-128. https://doi.org/10.1207/s15327906mbr3901_4

Maharjan, S. (2012). Association between Work Motivation and Job Satisfaction of College Teachers. Administrative and Management Review, 24(2), 45-55. 
Malik, M. I., Gomez, S. F., Ahmad, M., \& Saif, M. I. (2010b). Examining The Relationship of Work-Life Balance, Job Satisfaction, \& Turnover In Pakistan. International Journal of Sustainable Development, 2(1), 27-33.

Malik, M. I., Safwan, M. N., \& Sindhu, A, G. (2011). Examining Stress, Job Satisfaction and Customer Satisfaction in a Transport Company (A case from Pakistan). International Journal of Business and Social Science, 2(18), 81-85.

Malik, O. F., Waheed, A., \& Malik, K. U. R. (2010a). The Mediating Effects of Job Satisfaction on Role Stressors and Affective Commitment. International Journal of Business and Management, 5(11), 223-235. https://doi.org/10.5539/ijbm.v5n11p223

Manurung, S. P. (2017). The Effect of Direct \& Indirect Compensation to Employee's Loyalty: Case Study at Directorate of Huan Resources in PT POS Indonesia. Journal of Indonesian Applied Economics, 6(1), 84-102. https://doi.org/10.21776/ub.jiae.2017.007.01.6

Manyamba, V., \& Ngezi, T. (2017). The Effort Reward Imbalance model and work related stress in 3-5 Star hotels in Zimbabwe. African Journal of Hospitality, Tourism and Leisure, $6(2)$.

Margrit, A. (2017). Ritel Modern: Sinergi Jadi Kunci. http://kalimantan.bisnis.com/read/20170814/448/680518/ritel-modern-sinergi-jadi-kunci.

Accessed November 28, 2018.

Martocchio, J. J. (2015). Strategic Compensation A Human Resource Management Approach ( ${ }^{\text {th }}$ Editon). United States: Pearson.

Masihabadi, A., Rajaei, A., Koloukhi, A. S., \& Parsian, H. (2015). Effects of Stress on Auditors' Organizational Commitment, Job Satisfaction, and Job Performance. International Journal of Organizational Leadership, 4, 303-314. https://doi.org/10.33844/ijol.2015.60353

Matzler, K., \& Renzl, B. (2007). Personality Traits, Employee Satisfaction and Affective Commitment. Total Quality Management, 18(5), 589-598. https://doi.org/10.1080/14783360601061528

Men, L. R. (2014). Communication Channels and Employee Satisfaction Strategic Internal Communication: Transformational Leadership. Management Communication Quarterly, 28, 264. https://doi.org/10.1177/0893318914524536

Mondy, R. W., \& Martocchio, J. J. (2016). Human Resources Management, 14th Edition. England: Pearson.

Nahar, L., Hossain, A., Rahman, A., \& Bairagi, A. (2013). The Relationship of Job Satisfaction, Job Stress, Mental Health of Government and Non-Government Employees of Bangladesh. Psychology, 4(6). https://doi.org/10.4236/psych.2013.46074

Onsardi, A. M., \& Abdullah, T. (2016). The Effect Of Compensation, Empowerment, And Job Satisfaction On Employee Loyalty. International Journal of Scientific Research and Management (IJSRM), 05(12), 7590-7599. 


\section{Macrothink}

International Journal of Human Resource Studies

ISSN 2162-3058 2019, Vol. 9, No. 2

Pasebani, F., Mohammadi, S., \& Yektatyar, M. (2012). The relationship between organizational learning culture and job satisfaction and Internal service quality in sport organizations in Iran. Archives of Applied Science Research, 4(4), 1901-1905.

Pepra-Mensah, J., NtimAdjie, L., \&Agyei, A. (2017). Effect of Compensation on Basic School Teachers's Job Satisfaction in the Northern Zone: The Case of Ghana. Global Journal of Management and Business, 17(3), 50-59.

Prasetio, A. P., Yuniarsih, T., \& Ahman, E. (2017). The Direct and Indirect Effect of Three Dimension of Work-Life Interface Towards Organizational Citizenship Behahiour. Polish Journal of Management Studies, 15(1), 174-184. https://doi.org/10.17512/pjms.2017.15.1.17

Preacher, K. J., Rucker, D. D., \& Hayes, A. F. (2007). Addressing moderated mediation hypotheses: theory, methods, and prescriptions. Multivariate Behavioral Research, 42(1), 185-227. https://doi.org/10.1080/00273170701341316

Primadhyta, S. (2018). Meneropong Awan Mendung di Industri Ritel. https://www.cnnindonesia.com/ekonomi/20180208105641-92-274757/meneropong-awan-me ndung-di-industri-ritel. Accessed November 28, 2018.

Rahmah, G., \& Hamdi, I. (2017). Bisnis Online Kuasai 1,8 Persen Pasar Ritel. https://fokus.tempo.co/read/1005342/bisnis-online-kuasai-18-persen-pasar-ritel/full\&view=o k. Accessed November 28, 2018.

Rai, S. (2016). The Importance of Job Satisfaction. https://www.linkedin.com/pulse/importance-job-satisfaction-sanjay-rai/. Accessed November, 282018.

Raziq, A., \& Maulabakhsh, R. (2015). Impact of Working Environment on Job Satisfaction. Procedia Economics and Finance, 717-725. https://doi.org/10.1016/S2212-5671(15)00524-9

Rehman, S., Khan, M. A., \& Afzal, H. (2010). An Investigative Relationship between Efforts-Rewards Model and Job Stress in Private Educational Institutions: A Validation Study. International Journal of Business and Management, 5(3), 42-51. https://doi.org/10.5539/ijbm.v5n3p42

Robbins, S. P., \& Judge, T. A. (2017). Organizational Behavior 17th Edition. England Jersey: Pearson Education Inc.

Rothfelder, K., Ottenbacher, M. C., \& Harrington, R. J. (2013). The impact of transformational, transactional and non-leadership styles on employee job satisfaction in the German hospitality industry. Tourism and Hospitality Research, 12(4), 201-214. https://doi.org/10.1177/1467358413493636

Salisu, J. B., Chinyio, E., \& Suresh, S. (2015). The impact of compensation on the job satisfaction of public sector construction workers of jigawa state of Nigeria. The Business and Management Review, 6(4), 282-296. 
Schermerhorn, Jr. J. R., Osborn, R. N., Uhl-Bien, M., Hunt, J. G. (2012). Organizational Behavior, $12^{\text {th }}$ edition. New Jersey: John Wiley \& Sons.

Sekaran, U., \& Bougie, R. (2016). Research Methods for Business: A Skilled Building Approach, 7th Edition. United Kingdom: John Wiley \& Sons.

Shahid, M. N., Latif, K., Sohail, N., \& Ashraf, M. A. (2011). Work Stress and Employee Performance in Banking Sector. Evidence From District Faisalabad, Pakistan. Asian Journal of Business and Management Sciences, 1(7), 38-47.

Sheraz, A., Wajid, M., Sajid, M., Qureshi, W. H., \& Rizwan, M. (2014). Antecedents of Job Stress and its impact on employee's Job Satisfaction and Turnover Intentions. International Journal of Learning \& Development, 4(2), 204-226. https://doi.org/10.5296/ijld.v4i2.6098

SHRM. (2016). Employee Job Satisfaction \& Engagement. Revitalizing a Changing Workforce. Research Report by The Society of Human Resources Management.

Sieger, P., Bernhard, F., \& Frey, U. (2011). Affective commitment and job satisfaction among non-family employees: Investigating the roles of justice perceptions and psychological ownership. Journal of Family Business Strategy, 2, 78-89. https://doi.org/10.1016/j.jfbs.2011.03.003

Siegrist, J. (2012). Effort-reward imbalance at work - theory, measurement and evidence. Department of Medical Sociology, University Dusseldorf, Germany.

Singh, P., \& Loncar, N. (2010). Pay Satisfaction, Job Satisfaction and Turnover Intent. Relations Industrielles / Industrial Relations, 65(3), 470-490. https://doi.org/10.7202/044892ar

Smith, L. A., Roman, A., Dollard, M. F., Winefield, A. H., \& Siegrist, J. (2005). Effort-Reward Imbalance at Work: The Effects of Work Stress on Anger and Cardiovascular Disease Symptoms in a Community Sample. Stress and Health, 21, 113-128. https://doi.org/10.1002/smi.1045

Stringer, C., Didham, J., \& Theivananthampillai, P. (2011). Motivation, pay satisfaction, and job satisfaction of front-line employees, Qualitative Research in Accounting \& Management, 8(2), 161-179. https://doi.org/10.1108/11766091111137564.

Sun, Y., Gergen, E., Avilla, M., \& Grenn, M. (2016). Leadership and Job Satisfaction: Implications for Leaders of Accountants. American Journal of Industrial and Business Management, 6, 268-275. https://doi.org/10.4236/ajibm.2016.63024

Terera, S. R., \&Ngirande, H. (2014). The Impact of Rewards on Job Satisfaction and Employee Retention. Mediterranean Journal of Social Science, 5(1), 481-487. https://doi.org/10.5901/mjss.2014.v5n1p481

Tessema, M. T., Ready, K. J., Embaye, A. B. (2013). The Effects of Employee Recognition, Pay, and Benefit on Job Satisfaction : Cross Country Evidence. Journal of Business and Economics, 4(1), 1-12. 


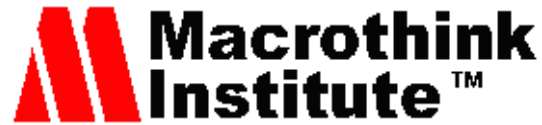

International Journal of Human Resource Studies ISSN 2162-3058 2019, Vol. 9, No. 2

Thaief, I., Baharuddin, A., Priyono, \& Idrus, M. S. (2015). Effect of Training, Compensation and Work Discipline against Employee Job Performance (Studies in the Office of PT. PLN (Persero) Service Area and Network Malang). Review of European Studies, 7(11), 23-33. https://doi.org/10.5539/res.v7n11p23

Tosun, N., \& Ulusoy, H. (2017). The relationship of organizational commitment, job satisfaction and burnout on physicians and nurses?. Journal of Economics and Management, 28(2), 90-111. https://doi.org/10.22367/jem.2017.28.06

Tran, H. (2016). The impact of pay satisfaction and school achievement on high school principals' turnover intentions. Educational Management Administration \& Leadership, 1-18. https://doi.org/10.1177/1741143216636115

Trivellasa, P., Reklitisa, P., \& Platis, C. (2013). The effect of job related stress on employees' satisfaction: A survey in Health Care. Procedia - Social and Behavioral Sciences - The 2nd International Conference on Integrated Information, 73, 718-726. https://doi.org/10.1016/j.sbspro.2013.02.110

Tziner, A., Rabenu, E., Radomski, R., \& Belkin, A. (2015). Work Stress and Turnover Intentions Among Hospital Physicians: The Mediating Role of Burnout and Work Satisfaction. Journal of Work and Organizational Psychology, 31, 207-213. https://doi.org/10.1016/j.rpto.2015.05.001

Usman, S., Akbar, M, T., \& Ramzan, M. (2013). Effect of Salary and Stress on Job Satisfaction of Teachers in District Sialkot, Pakistan. IOSR Journal of Humanities And Social Science (IOSR-JHSS), 15(2), 68-74. https://doi.org/10.9790/0837-1526874

Uzer, S. (2017). Happy Employee, Happy Client: The Importance of Job Satisfaction in a Results-Focused Environment. https://www.huffingtonpost.com/entry/happy-employee-happy-client-the-importance-of-job_ us_58b884b0e4b0fa65b844b113. Accessed November 28, 2018

Venkataraman, P. S., \& Ganapathi, R. (2013). A Study of Job Stress on Job Satisfaction among the Employees of Small Scale Industries. IOSR Journal of Business and Management (IOSR-JBM), 13(3), 18-22. https://doi.org/10.9790/487X-1331822

Vidal, M. E. S., Valle, R. S., \& Aragón, M. I. B. (2007). Antecedents of repatriates' job satisfaction and its influence on turnover intentions: Evidence from Spanish repatriated managers. Journal of Business Research, 60, 1272-1281. https://doi.org/10.1016/j.jbusres.2007.05.004

Wani, K. S. (2013). Job stress and its impact on employee motivation: a study of a select commercial bank. International Journal of Business and Management Invention, 2(3), 13-18.

Weyers, S., Peter, R., Boggild, H., Jeppesen, H. J., \& Siegrist, J. (2006). Psychosocial work stress is associated with poor self-rated health in Danish nurses: a test of the effort-reward imbalance model. Scandinavian Journal of Caring Sciences, 20, 26-34. https://doi.org/10.1111/j.1471-6712.2006.00376.x 


\section{Macrothink}

International Journal of Human Resource Studies

ISSN 2162-3058 2019, Vol. 9, No. 2

Whitt, W. (2006). The impact of increased employee retention on performance in a customer contact centre. Manufacturing and Service Operation Management, 8(3), 235-252. https://doi.org/10.1287/msom.1060.0106

Wolff, M. B., Gay, J. L. Wilson, M. G., DeJoy, D. M., \& Vandenberg, R. J. (2016). Does Organizational and Coworker Support Moderate Diabetes Risk and Job Stress Among Employees?, American Journal of Health Promotion, 1-4. https://doi.org/10.1177/0890117116685802

Workplace Health \& Safety Australia. (2014). WorkCover. Recognition and reward minimising work-related stress.

Yamoah, E. E. (2013). Relationship Between Compensation and Employee Productivity. Singaporean Journal of Business Economics and Management Studies, 2(1), 110-114. https://doi.org/10.12816/0003845

Yang, J. Y. (2010). Antecedents and consequences of job satisfaction in the hotel industry. International Journal of Hospitality Management, 29, 609-619. https://doi.org/10.1016/j.ijhm.2009.11.002

Zangaro, G. A., \& Soeken, K. L. (2007). A Meta-Analysis of Studies of Nurses' Job Satisfaction. Research in Nursing \& Health, 30, 445-458. https://doi.org/10.1002/nur.20202 


\section{Macrothink}

International Journal of Human Resource Studies

ISSN 2162-3058

2019, Vol. 9, No. 2

\section{Appendix}

\section{Appendix 1. Items for Constructs}

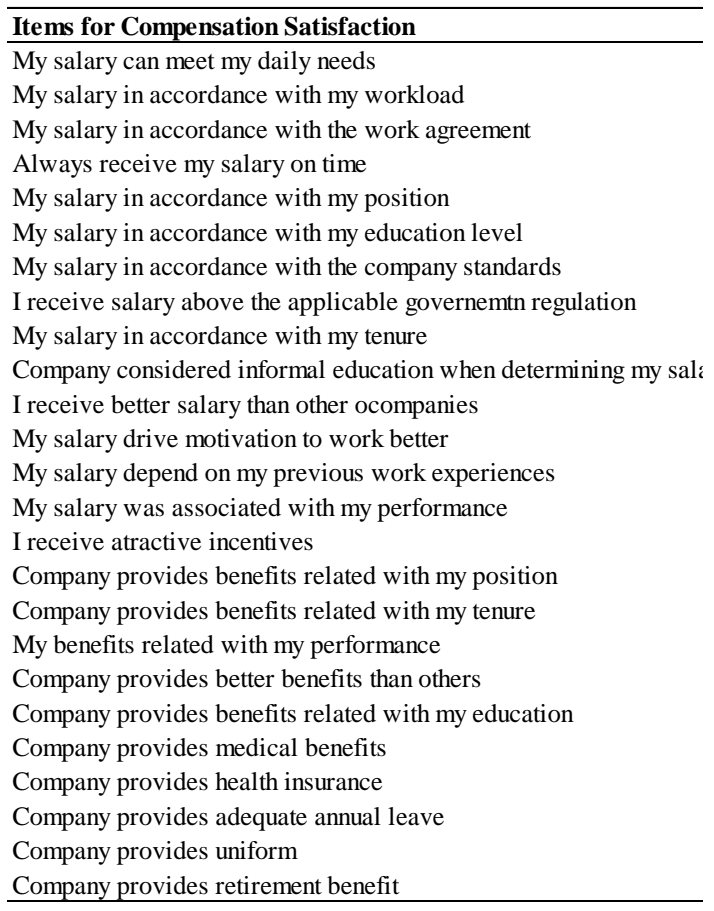

Items for Work Stress

I feel exhausted after work

I don't have enough time after work

Having a lot of problems at work

The work demands take a lot of my time \& energy

My job is very demanding

Having difficulty to finish my work

My job is not in accordance with my abilities

Think about work when I am at home

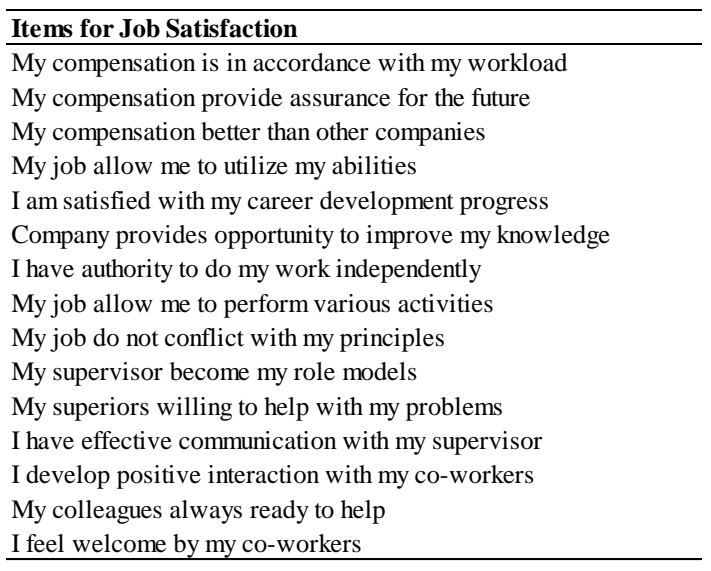

\section{Copyright Disclaimer}

Copyright for this article is retained by the author(s), with first publication rights granted to the journal.

This is an open-access article distributed under the terms and conditions of the Creative Commons Attribution license (http://creativecommons.org/licenses/by/4.0/). 